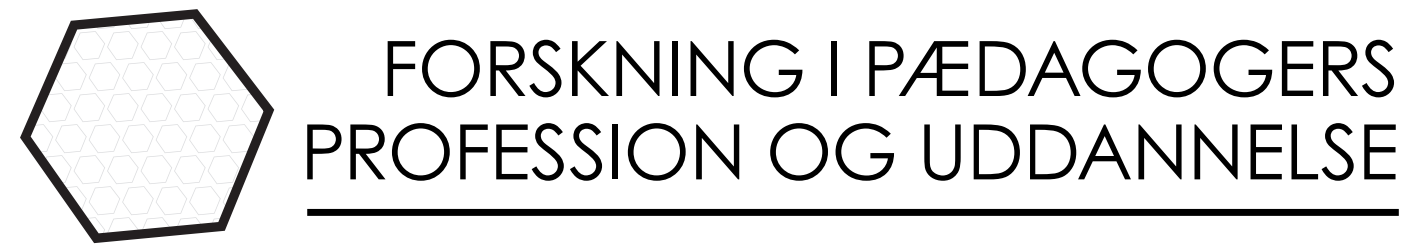

\title{
Legende samspil, frihed og rammer i det paedagogiske miljø \\ Narrative strukturer giver orienteringspunkter i hverdagen
}

\section{Hanne Hede Jørgensen}

lektor, VIA-UC,HHJ@via.dk

\section{Anette Boye Koch}

ph.d., docent, VIA-UC 


\title{
Resume
}

Med afsæt i et eksempel fra forskningsprojektet 'Det gode børnemiljø' vises, hvordan en pædagog i en børnehave og inden for rammerne af et fortælleværksted indgår i legende samspil med en større gruppe børn. Gennem det legende samspil og ved at forbinde sig til børnenes ideer og inddrage deres perspektiver, støtter pædagogen deres deltagelse i aktiviteten. Med udgangspunkt i en narrativ analyse af fortælleværkstedet belyses og diskuteres, hvordan pædagoger og børn sammen udvikler narrative strukturer, som de bruger til at navigere i et institutionsliv, hvor meget foregår på én gang og på flere niveauer. Artiklen diskuterer, hvordan pædagoger kan anvende narrative strukturer til at skabe et godt poedagogisk miljø, hvor 'det gode' knyttes til børns muligheder for deltagelse i hverdagslivet, mens 'det pædagogiske' knyttes til pædagogers evne til at være både legende og rammesættende i deres samspil med børn.

\begin{abstract}
Based on an example from the research project 'the good child environment' the article illustrates how a pedagogue in a kindergarten and within the settings of a storytelling-session engages in play-full interactions with a large group of children. The play-full interactions motivate the children's participation in the activity by connecting to their ideas and including their perspectives. Narrative analysis of the story-telling session shows - analytically - how pedagogues and children develop narrative structures, which are used on a daily basis to navigate in an institutional life where much is at stake simultaneously. The article discusses how narrative structures are useful in order to generate a good pedagogical environment in which 'good' is understood as children's possibilities to navigate and participate in everyday life, and 'pedagogical' is understood as a professional balance between managing settings and acting playfully.
\end{abstract}

\section{Nøgleord}

Pædagogisk miljø, børns perspektiver, legende samspil, narrativ analyse, narrative strukturer. 


\section{Indledning}

En sørøverfortælling begynder med en kurv En padagog kommer slobende med en kurv, som sattes ind $i$ det rum, der kaldes
gymnastiksalen. Straks kommer tyve børn løbende og slår sig ned omkring kurven.
De mindre børn, der var $i$ gang med at hoppe på madrassen, løber ud af rummet, og
de store børn sørger for at få lukket ud til gangen, for nu goelder det fortcellevcerkste-
det.

Herefter indleder poedagogen fortcellingen med at sige: "Jeg skal bruge én". Sytten hoender ryger op. De sidste tre tøver, men har ansigtet ivrigt vendt mod pcedagogen. "Men det skal voere en der er modig og sej!" fortscetter poedagogen. Mindst femten hoender ryger op. Pcedagogen valger Roar: "Ved du hvorfor, jeg valgte dig?" Alle holder vejret. "Fordi du har stribet tøj på!" Flere børn gør opmoerksom på, at det har de også. "Vi skal lave dig lidt om", siger pcedagogen, og mens pcedagogen leder $i$ kurven, begynder børn at gæette på, hvad der skal fortcelles om. "En zebra"? Men så får Roar et tørklcede om hovedet og en klap for øjet, og børnene hujer: "En pirat"!"

(Feltnote, 04.11.16)

Således begynder en fortælling om et fortælleværksted i en daginstitution. Fortællingen er denne artikels omdrejningspunkt. I artiklen tager vi udgangspunkt i en livsverdensforståelse, hvor fortællinger indgår i den menneskelige erfaring som en måde at orientere sig og skabe mening på i et mylder af stemninger, følelser, relationer og muligheder (Riessman 2017 m.fl.). Vi vægter en hermeneutisk tilgang til narratologien og er interesserede i at forstå, hvordan børn og pædagoger tillægger handlinger og udtryk i hverdagslivet mening og værdi. Fokus er dermed det performative og betydningsskabende i udviklingen af det gode pædagogiske miljø. Men vi er også, i forlængelse af narrative teorier, interesserede i, hvordan vi som forskere med vores blikke er med til at producere mening i og om feltet. Det narrative forskningsfelt har studier af det særlige som omdrejningspunkt og ofte tages afsæt i enkelte cases eller fortællinger, da fokus er på det partikulære frem for på identifikation af mønstre som i en klassisk etnografisk analyse (Riessman 2017 p.244). Det særlige, som vi retter opmærksomheden mod ved at knytte an til én enkelt fortælling i vores materiale, er de kulturbårne forståelser for det gode og rigtige, som vi kan analysere frem ved at anlægge et narrativt blik. Da fortællinger handler om normer og normbrud (Bruner 2004 p.22), kan de netop give indblik i, hvordan mennesker i en given kontekst - som en daginstitution - orienterer sig og interagerer på en baggrund af forestillinger om rigtigt og forkert, godt og skidt. Vi lægger os dermed i forlængelse af en pædagogisk forskning, der forstår pædagogisk praksis som værdibaseret og ikke-instrumentel, og hvor viden er noget, der udtrykkes i handlinger (Manen 2008 p.1). Den narrative analyse kan give et indblik i den kompleksitet, som udspiller sig i de pædagogiske handlinger. 


\section{Det gode børnemiljø og de metodologiske overvejelser}

Artiklen bygger på et eksempel fra forskningsprojektet Det gode børnemiljø, hvor vi undersøgte, hvordan pædagoger udmønter den lovbestemte forpligtelse til at inddrage børns perspektiver i udviklingen af det gode børnemiljø (Dagtilbudsloven $\S 7 \& 8,2016)$. Forskningsspørgsmålene var: Hvordan inddrager pædagoger børns perspektiver? Hvordan påvirker børns perspektiver den pædagogiske praksis? Og hvordan kan et børnemiljø vurderes som godt ud fra børns perspektiver? Artiklen her knytter an til det første af forskningsspørgsmålene og belyser, hvordan pædagoger i et legende samspil med børn inddrager deres perspektiver.

I forskningsprojektet har vi været optaget af bevægelserne mellem børn og pædagoger. Vi har ønsket at tage normativiteten omkring det 'gode' miljø alvorligt. Ikke som et udefrakommende måleredskab, men som en undersøgelse af, hvad pædagoger og børn selv forstår og værdsætter som gode og rigtige måder at interagere med hinanden på. Vi forstår fortællinger som "cultural plotlines" (Clandinin 2013 p.22), som vi lever i og med, i den forstand at vi genfortæller og indretter os efter dem, fordi de som oftest handler om gode og mindre gode måder at interagere på. Fordi fortællinger tematiserer 'det gode' og 'det mindre gode', kan de tilbyde mennesker i en given kultur orienteringspunkter i en verden, hvor der er mange veje at gå, men hvor ikke alle veje er 'den rette'. Som sådan fremstår fortællinger normative; som et moralsk anliggende og som handlingsanvisende (Togsverd et al. 2017 p. 89). Det gode og det mindre gode er nemlig afhængig af den sammenhæng, hvori det optræder. Derfor er narrative studier optaget af at undersøge de kontekstuelle og relationelle forhold omkring fortællinger (Clandinin 2013 m.fl.).

Børnemiljøprojektet tager udgangspunkt i et "Short-term" etnografisk feltstudie (Pink \& Morgan 2013). Studiet er foretaget i to institutioner i en periode på 8 måneder. Vi har foretaget interviews af pædagoger i begyndelsen og i slutningen af projektet. Vi har afholdt narrative workshops med pædagoger med henblik på udveksling af fortællinger om det gode børnemiljø (Author, 2018). Vi har i samarbejde med pædagoger og børn og med udgangspunkt i fotografier, taget af børn, afholdt 2 x 2 børnemøder i hver institution, hvor børn har fortalt om det gode og det dårlige i børnehaven. Endelig har vi lavet deltagerobservationer med fokus på børn og pædagogers samspil i sammenlagt 14 dage i hver institution.

\section{Børns perspektiver og artiklens forskningsbidrag}

VI forstår børns perspektiver som et relationelt fænomen (Bae 2012 p.48) knyttet til deres kommunikationsformer og lyst til at være del af legen og fællesskabet. Børn er med andre ord optaget af hinanden og af at tage del i morskaben. Derfor søger de veje til aktivt at skabe bevægelser, bruge kroppen og sætte rammer og regler i spil med det formål at have det sjovt sammen. Ud fra en sådan forståelse af børns perspektiver er leg og morskab 'det gode'. At indgå i det legende samspil, 
som børn praktiserer og inviterer til, kan således forstås som en inddragelse af børns perspektiver.

På den baggrund har vi rettet fokus mod, hvordan pædagoger møder og inddrager det legende, som en integreret del af institutionens hverdagsliv. Vi er interesserede i, hvordan pædagoger formår at indgå i legende samspil, der hvor det ud fra kendskabet til det enkelte barn og til børnegruppen skønnes det rigtige at gøre. Kan vi fx forstå det legende som et mødested, hvor børnenes 'her og nu' perspektiv tilkendes betydning, samtidig med at pædagogerne bevarer overblikket over egne pædagogiske mål for børnene? Og i så fald hvilke krav stiller det så til pædagogen?

Fortællingen fra gymnastiksalen om "Roar som pirat" er nedskrevet på feltarbejde i forbindelse med vores projekt. Den viser en pædagog i et fortælleværksted, som han styrer ved at indgå $\mathrm{i}$ et legende samspil med børnene. Pædagogen forbinder sig med børnenes ideer og bidrager til morskaben ved at improvisere og handle ud fra et kendskab til deres optagetheder. Han trækker på elementer, der engagerer og morer børnene som eksempelvis processen med at blive valgt og gætte, hvad der skal fortælles om. Samtidig forbinder han sig til den sørøverhistorie, børnene i øjeblikket er optaget af at lege i snart sagt alle institutionens fysiske rum. Men eksemplet viser også, at pædagogen ikke aktivt gør noget for at erindre børnene om fortælleværkstedets rammer eller justere på dem. Hverken for de deltagende i Storebørnsgruppen, der stimler sammen og lukker døren, eller for de små i Mellem- og Småbørnsgruppen, der skynder sig ud. Rammerne ser ud til at gøres og leves af børnene. Og aktiviteten, der engagerede de tyve børn og pædagogen, varede denne dag ifølge feltdagbogen lidt over en time.

Artiklens formål er at åbne for samtaler om gode pædagogiske miljøer ved at tilbyde nye begreber. På baggrund af analysen og i overensstemmelse med narrativ teori, formulerer vi afslutningsvis teoretiske udsagn, idet vi udleder tre narrative stukturer. Vi lægger op til en diskussion af, hvordan narrative strukturer kan anvendes til at stille skarpt på nogle af de mindre synlige pædagogiske ressourcer, som vi finder, fortjener faglig opmærksomhed og refleksion. Sørøverfortællingen er udvalgt, da den på mange måder fremstod som et eksempel på, hvordan et godt børnemiljø kan praktiseres, og vi ønsker at rette fokus mod kompleksiteten i de meningsskabende processer mellem rammer, identiteter og kulturelle fællesskaber, som børn og pædagoger deltager i og skaber. Samtidig gør vi opmærksom på, at den fortælling, vi analyserer, er en 'levet fortælling' (Clandinin 2013 p. 21). Fortællingen bliver først til tekst i det øjeblik, den nedskrives af os. Analyse og fortolkning af fortællingen, bliver til endnu en fortælling; en forskerfortælling om 'det gode', men det gode kan opsluges af rutiner og blive mindre godt. Forskerfortællinger har ikke til hensigt at give en neutral beskrivelse af virkeligheden, men ved hjælp af eksemplet at inspirere til "mouvements of thoughts" (Frank 2012 p.73). I vores artikel til tanker om, hvordan det gode miljø vedvarende kan være godt for alle. 


\section{En sørøverhistorie Begyndelsen - Fortcellevœrkstedets Drejebog}

Enhver levet fortælling har en forhistorie, bundet til de liv, identiteter, fællesskaber og rutiner, der er dens kontekst. Idet pædagogen i eksemplet griber fat i den store kurv, sker der noget. Kurvens tilsynekomst i gymnastiksalen er den peripeti, dvs. "omslag til det modsatte" (Aristoteles 2004 p. 71), der sætter fortællingen i gang. Børnene ændrer retning. Kolbøtter, madrasrulninger og ribbeklatringer stopper. De små løber ud. De store skynder sig at løbe efter pædagogen med kurven, mens de med glade øjne vendt mod forskeren råber: "Vi skal lave historie". Det, der for forskerens øjne i første omgang ligner et pludseligt ugennemskueligt mylder af børn, bliver til børn, der finder deres pladser i forhold til en kendt ramme. De store børn lukker døren efter de små. Kurven stilles på gulvet. Børnene sætter sig i en halvkreds omkring den. Der er (næsten) stille.

Fortælleværkstedet har tydeligvis resonans i børnegruppen. Børnene genkender det som noget godt, og det lader til at initiere en bestemt form for adfærd i børnegruppen. Både for de, der skal deltage, og de, der ikke skal. Noget, de organiserer sig efter, som var der en usynlig Drejebog tilstede. Sådan kan det i en narrativ optik se ud: Hvis vi forstår aktiviteten, fortælleværkstedet, som en levet fortælling med et genkendeligt handlingsforløb opbygget som en klassisk lineær fortælling med begyndelse, midte og slutning (Aristoteles 2004 p.67), kan vi forstå pædagogiske aktiviteter som forløb med narrative strukturer, der virker støttende og styrende for børnenes selvregulering. Kurven initierer begyndelsen til fortælleværkstedet. Den er det artefakt, hvorom drejebogen udspiller sig. Levede fortællinger er netop kendetegnede ved at udspille sig i relationen mellem den fysiske verden, ting, steder og mennesker (Clandinin 2013 p.23). En drejebog kan således være en måde at støtte og ordne børns erfaringer og oplevelser på som særlige kulturelle 'plotlines', de kan genkende og orientere sig efter. Ifølge Katrine Nelson har barnet allerede tidligt brug for sådanne drejebøger, eller "scripts" (Nelson 2007 p.89), fordi narrative strukturer hjælper barnet til at forudsige og skabe mening i hverdagen. Drejebøgerne foreskriver rigtige og forkerte måder at agere og opføre sig på i situationen, samtidig med at de inddeler dagen i små, overskuelige forløb. Hvis vi forstår fortælleværkstedet som en tilbagevendende aktivitet, som pædagogen har rammesat og over tid har levet og gjort med børnene, kan det tilbyde os en forståelse for, hvordan børnene så præcist kan vide, hvad der forventes af dem. De ved ganske enkelt, hvad der skal ske, og hvem der skal med, når kurven rituelt bæres ind i gymnastiksalen. Børnene kender omtrentlig varighed og rækkefølge for, hvad der skal ske. De håndhæver selv rammerne ved at lukke døren og sætte sig omkring kurven, og der er ingen protester fra de små, der tilsyneladende er helt på det rene med at skulle noget andet. 


\section{Institutionens narrative repertoire}

Som det fremgik af det indledende glimt ind i fortælleværkstedet, reagerede børnene med hujende glæde på Sørøverfortællingen. Vi nævnte ligeledes, at børnene i institutionen for tiden er optaget af en piratleg. Legen ses på legepladsen i form af flere børn omkring et stort træskib. Andre gange ses et enkelt barn løbe rundt en hel dag med et tørklæde om håret og en klap, der sidder lidt på skrå over det ene øje og levner en sprække at se ud af. Piratlegen bevæger sig mellem alle institutionens fysiske rum og aktører. Vi ser den som en del af institutionens narrative repertoire, som er "stories that a person at least recognizes and a group share" (Frank 2012 p. 53). Vi forstår en institutions narrative repertoire bredt som institutionens fællesgods af kulturelle udtryksformer som fortællinger, sange, vittigheder, lege m.m. Heraf kan nogle være initieret af pædagogerne som fx nye sange eller en Bamseven, ${ }^{1}$ mens andre kan være initieret af børn som fx Batman eller andre mediehelte og -skurke, der dukker op i institutionen (Feltnote 03.11.16). I eksemplet her er det uvist for forskeren, hvor piratlegen kommer fra, men den opleves tydeligvis af børnene som meningsfuld, og i fortælleværkstedet gribes den af pædagogen, der viser forståelse for, at børnene allerede kan have - eller finder det meningsfuldt at have - et piratlegenavn.

"Kan du sige som en pirat?" Roar brøler højt, og de andre børn griner. "Hvad skal han hedde?" Poedagogen spørger flokken og ser så på Roar: "Har du et sørøvernavn"? "Sørøverkaptajn Roar" råbes der fra flokken.

Løbende inddrages de andre børn, når der er roller i fortællingen, der skal besættes. Børnene melder sig, mens fortællingen skrider frem i en vekselvirkning mellem pædagogens greb ned i kurven og børnenes engagerede gætterier og forslag. Der synes at opstå en fælles bestræbelse på at skabe sammenhæng i fortællingen med de artefakter, som pædagogen får fat i nede i kurven, og de idéer børnene har. Sørøverhistorien har nok resonans i gruppen af børn og pædagoger som en del af institutionens narrative repertoire, men ikke som en bestemt sørøverhistorie med et fast plot og faste figurer. Der er tværtimod mange sørøverfortællinger i spil i institutionen med mange forskellige fragmenter, rekvisitter, figurer, artefakter med mere, der hører til i den sammen store sørøverhistorie. Under fortælleværkstedet leges en sørøverfortælling frem i samspillet mellem børn og pædagoger. Pædagogen responderer på børnenes ideer, også dem, der afvises. Alle ideerne bruges i en dialog om artefakter og sørøverfortællinger, som det fremgår nedenfor:

Da Roar er forvandlet til pirat spørges: "Er han fordig nu? Mangler der noget?" Et barn svarer: "En papegøje!" Pœedagogen: "Det ku' det vœre, men det er nu ... skceg. Må jeg male skceg på dig?" Frem fra kurven drages en ansigtstush, mens der går et sus ned gennem sørøverne.

1 Fra "Fri for Mobberi" konceptet, Mary-fonden. 
Institutionens narrative repertorie indbefatter også kendskab til andre børnekulturelle genrer som eventyr og gåder. Børnene ved fx, at man i enhver god fortælling har tre forsøg til at nå sit mål. Efter at Sørøverkaptajn Roar og hans mænd er faldet ned ad en mudret bakke to gange, bidrager børnene til fortællingen på følgende måde:

\section{Poedagogen: "Men tredje gang ..."? \\ "Dér faldt de ikke", råber børnene.}

Sammen udtænker pædagog og børn så en måde, hvorpå hele sørøverflokken kan komme op ad bakken igen.

\section{Narrativ habitus}

Mens repertoiret er de fortællinger, sange m.m. som børn og pædagoger er fælles om at kende til, er deres narrative habitus en individuel og kropsligt indlejret viden om gode og dårlige fortællinger (Frank 2012 p.52). Hvorfor opleves en fortælling som god? Hvad vækker jubel, og hvad vækker modstand? Hvilke elementer hører med i en god sørøverfortælling? Den narrative habitus er individuel, men kan udveksles og udvikles i fællesskabet mellem børn og pædagog. Da pædagogen fx spørger, om de ved, hvorfor de skal sejle?, bringer et barn sin viden i spil: "Fordi de skal plyndre!" Plyndringer er en del af sørøverfortælleuniversets logik, men så brydes logikken af et barn:

\section{Et barn råber, mens han skoggerler: "Han ligner en gammel kone". Pcedagogen lukker af med et: "Nej, han gør da ej".}

Skoggerlatter, eller hånlatter (Søbstad 2006 p. 43) er tilsyneladende et brud i sørøverfortællingen og ikke af 'det gode'. Børnene accepterer og retter ind. Men også pædagogen kommer til at 'ødelægge' sørøverfortællingen:

\footnotetext{
"Hov, noget falder ud af en bog. Hvad kan det voere?" Der gattes: "Et kort?" "Et sørøverkort" "Et skattekort". Poedagogen trckker en i-pad med et billede af et kort op af kurven. Børnene cendrer fokus, nogle går hen til i-paden. En dreng: "Hvem er de der andre på billedet?" Podagogen: "Det er nogle sørøvere fra et andet skib. Vil I hjoelpe med at finde skatten"? "JAAAAAA", råber børnene og begynder hoppe, nu igen med fokus på poedagogen, der har hånden $i$ kurven.
}

De små brud kunne have afsporet fortælleseancen, men gør det ikke. For både børn og pædagoger er engagerede i at fortælle en god sørøverfortælling. Pædagogen bruger den viden, som børnene bringer i spil til at justere både børnene og sig selv til at blive i fortælleuniverset. At blive drillet med at ligne en gammel kone, hører tilsyneladende ikke med i en god sørøverfortælling. Og i-paden lader til at være et forstyrrende artefakt, der ikke har plads i en sørøverfortælling og derfor 
truer med at nedbryde hele seancen. Men forventninger om en nedgravet skat får dem alle tilbage på sporet. Den narrative habitus sættes i spil og hjælper børn og pædagoger til sammen at skabe drama og finde løsninger, der trækker fortællingen i nye retninger, men samtidig sikrer, at de bliver i sørøveruniverset.

\section{Det legende samspil - latter og bevagelse}

Drejebogen for fortælleværkstedet, institutionens narrative repertoire og børn og pædagogers narrative habitus kan ses som særlige, narrative strukturer, der giver børn mulighed for at deltage $\mathrm{i}$ aktiviteten og bidrage til, at den kan udvikle sig i en retning, der giver mening for dem. Men det er ikke nok til at forklare, hvorfor de forventningsfulde og villige forlod den glade tumlen i ribber og på madrasser, da kurven gjorde sin entre.

Børnenes forventninger ser ud til at være rettet mod pædagogens særlige evne til at fortælle historier, hans vilje til aktivt at gå ind i deres legende samspil og lege med. Det gør han bl.a. ved at appellere til deres trang til at bevæge deres kroppe.

\section{Pcedagogen fortceller, hvordan sørøverbescetningen når frem til øen ved at gå og gå og gå. De fleste børn har rejst sig, deres kroppe imiterer inertien i pcedagogens stemme, indtil han råber: "Hov! Der var en slange". Alle børn stopper bevcegelsen. "Kan du ikke hakke den, Roar?" Roar hakker og hakker. "Skynd dig, hak den! Det skal altså vore mere". Børnene står toet omkring poedagogen, Roar og den grønne tøjslange, de griner og griner og hakker med alt hvad de kan.}

Med en fænomenologisk tilgang kan vi forstå børn som kropssubjekter, der aktivt og kropsligt involverer sig i samspil med andre børn og pædagoger om at skabe mening i hverdagen (Løkken 2000 p.22). Når børn har brug for at bevæge sig under en fortælleseance, kan det således være, fordi de søger mening i kroppen. Og når pædagogen inviterer dem til at 'tale' med kroppen, kan det forstås som en genkendelse af børns behov for at forstå med hele kroppen. Børnekroppe i bevægelse kan altså tolkes som tegn på engagement og deltagelse, og børns generelle optagethed af ting, der bevæger sig, kan forstås som et kropsligt forankret videbegær. Bevægelse er imidlertid ikke blot en fysisk aktivitet. Også latter kan forstås som en bevægelse, og pædagogen appellerer flere gange direkte til børns humor med bemærkninger, der får latteren til at rulle gennem gruppen.

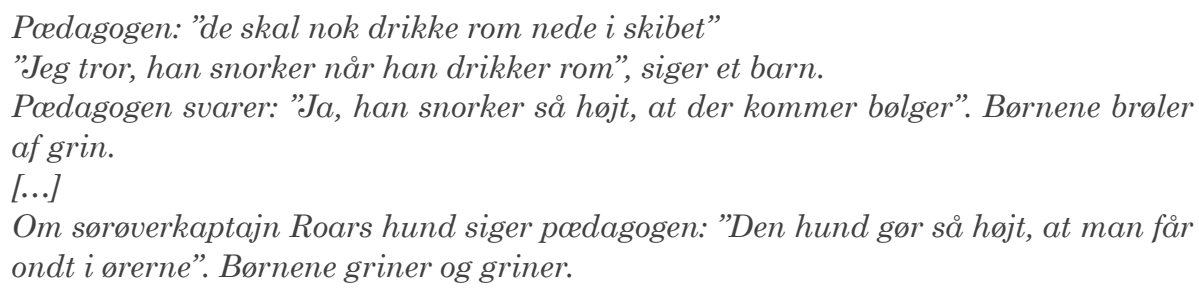


Børn ler bl.a. af inkongruens, dvs. fordrejninger og modsætninger som grimasser og påklædning, bevægelser eller udseende, der bryder med det vante (Søbstad 2006 p.49). Med reference til Bakhtin betegnes børns latter ofte som karnevalsk, med flair for det groteske, det omvendte og kropslige og som en modstandslatter rettet mod voksnes rammer (Tallant 2017 p.82). Den latter, der griber børnene her, er ikke en modstandslatter, for de ler sammen med en pædagog, der leger med. Ydermere stimulerer han latteren ved at appellere til deres humor, mens han afviser den 'forkerte' hånlatter. Latteren, der bølger gennem børnegruppen, kan ses som del af det legende, der set ud fra Gadamers hermeneutiske filosofi bevæger sig i en hid-og-did-bevægelse uden retning og andre formål end at blive ved (Gadamer 2004 p.101 ff). Hvis vi med inspiration fra Gadamer forstår den legende latter som retningsløs, er denne bevægelse forbundet med både frihed og risiko. Frihed, fordi det retningsløse indeholder muligheder. Risiko, fordi det retningsløse kan tage overhånd, og man risikerer at fortabe sig i kaos. For barnet bliver det vigtigt at turde kaste sig ud i latteren og være med i den smittende bevægelse, der bølger mellem dem og efterlader en oplevelse af samvær og fællesskab. Samtidig får de erfaring med at være i det retningsløse, det åbne og potentielt kaotiske. Pædagogens dobbeltrolle består her i både at bidrage til det legende, samt med sin tilstedeværelse at rammesætte på en måde, så ethvert barn tør og kan deltage. Det kunne de tilsyneladene i fortælleværkstedet. Leg og fortolkning er jf Gamdamer beslægtede som åbne og retningsløse processer, hvilket lægger op til at diskutere fortælleværkstedets dannelsespotentiale. Forstået således, at fortælleværkstedet bliver en legeplads for fortolkningsprocesser, hvori børn og pædagoger har mulighed for at mødes ligeværdigt som meningsskabende og deltagende subjekter (Skoglund 2014 p. 38). Det er op til pædagogen at sikre, at alle børn får den mulighed.

\section{Afrunding}

Med udgangspunkt i en narrativ analyse har vi formuleret en forskerfortælling om det gode miljø i daginstitutionen. Vi har peget på, at dette miljø kan forstås som hvilende på en grund af narrative strukturer, der fortjener faglig opmærksomhed. Men de kræver også refleksive pædagoger, da 'det gode' kan forsvinde i uovervejede rutiner og blive 'mindre godt'; forstået som upædagogisk. Vi har i artiklen formuleret tre typer af narrative strukturer:

Den Narrative Habitus, karakteriseret som individuel viden om fortællinger. Vi ser den som et pædagogisk potentiale for samtaler om det kontekstuelt 'gode', i forhold til hvad, der hører med og gør fortællinger, fiktive såvel som levede, gode. Vores analyse tager udgangspunkt $\mathrm{i}$ en sørøverfortælling, men narrativ habitus handler også om det "corpus of stories" (Frank 2012 p. 194), vi lever efter og tænker med. Narrativ habitus har dermed også betydning for de forestillinger om det gode, som vi gør os om os selv og verden. Vi har ikke systematisk undersøgt, hvordan pædagogerne sikrer sig at alle børns narrative habitus understøttes og 
inddrages i pædagogiske aktiviteter og hverdagssamtaler. Et væsentligt opmærksomhedspunkt for 'det gode' vil derfor være, hvordan pædagoger møder de børn, hvis narrative habitus enten er forskellig fra pædagogens eller kun vanskeligt kommer til udtryk.

Institutionens Narrative Repertoire har vi karakteriseret som et fællesgods af kulturelle udtryksformer i form af fortællinger, sange, vittigheder, lege m.m. I vores fortælling ser det narrative repertorie ud til at være udviklet i krydsfeltet mellem børn og pædagogers perspektiver. Den viser 'det gode' som et ligeværdigt forhold mellem institutionens aktører i forhold til den kultur og det fællesskab, der skabes. Men et sådan ligeværd er ikke en selvfølge. Det fordrer pædagoger, der refleksivt og vedvarende forholder sig etisk undersøgende til det asymetriske i voksen-barn relationen og balancerer egne perspektiver med børnenes. Helt konkret kan det handle om at sikre, at børnenes initiativer gribes og gives plads. Men det kan også handle om at lægge faglige vurderinger til grund for de kulturelle indspil, man som voksen bringer ind i institutionens repertoire.

Den tredje struktur er de rammesættende Drejebøger. Vi ser disse som "stories" institutionens aktører er "caught up" i, og som 'fortæller' dem, hvad de skal lægge vægt på, og hvad der kan ignoreres (Frank 2012 p. 48). Det vil sige, de kan blive norm-bærende i institutionens forskellige rum som legepladsen, frokostbordet, samlingen m.m. I vores fortælling repræsenterer drejebøgerne 'det gode' i den forstand, at de giver retning og rammer hverdagen ind i overskuelige handlingsforløb, der tilbyder børn muligheder for at regulere sig selv samt frihed til at bevæge sig rundt i kendte rammer. Vi har i forskerfortællingen betonet det potentiale, som det legende samspil tilbyder i forhold til netop at rammesætte hverdagen på en måde, der er meningsfuld for børn. Et væsentligt opmærksomhedspunkt bliver imidlertid de børn, der har vanskelligt ved at deltage i legefællesskaberne, og som kræver en ekstra pædagogisk indsats for at kunne lege med. Et andet væsentlig opmærksomhedspunkt, når det legende samspil bliver normbærende for interaktioner mellem børn og pædagoger, er, i hvor høj grad børn kan 'forføres'? Sagt på en anden måde: Vil børn være med til 'hvad som helst', fordi de bliver mødt legende?

Vi har med vores analyse ønsket at åbne op for en diskussion af det gode pædagogiske miljø som et miljø, hvor pædagoger møder børns leg og latter som særlige udtryksformer, der kan sættes i spil, når børn skal inddrages og hverdagslivet rammesættes. Denne rammesætning kan understøttes gennem en faglig opmærksomhed på forskellige typer af narrative strukturer, men må samtidig kvalificeres gennem faglig refleksion og samtale.

\section{Litteratur}

Author (2018, in press): Pædagogers arbejde med børns perspektiver. Tidsskrift for socialpcedagogik.

Aristoteles (2004): Poetikken. København: Det lille Forlag. 
Bae, B. (2012): Kraften i lekende samspill. Potensial for medvirkning og ytringsfrihed. Bergen: Fagboklaget.

Bruner, J. (2004): At fortcelle historier i juraen, litteraturen og livet. København: Alinea.

Clandinin, D. J. (2013: Engaging in narrative inquiry. New York: Routledge.

Dagtilbudsloven. Bekendtgørelse af lov om dag-, fritids- og klubtilbud m.v. til børn og unge. Socialministeriet (2016).

Frank, A.W. (2012): Letting stories Breathe. University of Chicago Press.

Gadamer, H.G. (2004): Sandhed og metode. København: Hans Reitzels Forlag.

Løkken, G. (2000): Using Merleau-Pontyan phenomenology to understrand the toddler i: Nordisk Pedagogik, vol 20, nr. 1, p. 13-23.

Manen, M. von (2008): Pedagogical Sensitivity and Teachers Practical Knowing-in-Action http:// kortlink.dk/maxvanmanen/tesu, fundet 22-03-2018.

Nelson, K. (2007): Young minds in social worlds. USA: Harvard Press.

Pink, S. \& Morgan, J. (2013): Short-Term Ethnography: Intense Routes to Knowing. I: Symbolic Interaction, vol. 36 (3) p. 351-361.

Riessman, C.K. (2017): Narrativ analyse I samfundsvidenskaber i: Järvinen, M. \& Mik-Meyer, N. (red) Kvalitative analyser. Syv traditioner. København: Hans Reitzels Forlag.

Skoglund, R.I. (2014): Danning i barnehagen: Hva ka danningens "mer enn” være? Norsk Pedagogisk Tidsskrift. Årgang 98, vol. 1. s. 34-46.

Søbstad, F. (2006): Glede og humor i barnehagen. Oslo: Cappelen Akademisk Forlag.

Tallant, L. (2017): Embracing the Carnevalesque: Young Children's Humour as Performance and Communication. Knowledge Cultures p. 71-84.

Togsverd, L., Jørgensen, H.H., Rothuizen, J.J., Weise, S. (2017): Viden $i$ spil i daginstitutioner. Aarhus: DPP. Findes også på kortlink.dk/ucviden/tesy. 